\title{
ANALISIS STRATEGI PEMASARAN JAMUR RIMBA JAYA MUSHROOM
}

\author{
Arminsyurita \\ Sekolah Tinggi Ilmu Administrasi Mandala Indonesia \\ rizayoroshiku@yahoo.co.id
}

\begin{abstract}
Rimba Jaya Mushroom as companies engaged in the agribusiness industry in the procurement of vegetables and mushrooms to face the problem: unmet demand, the capacity of the products that do not satisfy the market demand and competition from companies that must be observed. Therefore, companies need a strategic move to float the mushroom's business in order to seize the opportunities facing the problem that continuity and corporate objectives can be achieved. This study aims to identify factors internal environment (Strengths, -Weakness) and external environmental factors (Opportunities-Threats) that affect marketing company, and analyze marketing strategies of Rimba Jaya Mushroom.

Based on the results of the SWOT matrix analysis charts and diagrams IE the company's marketing strategy can be recommended Rimba Jaya Mushroom, among others, by taking market share for market penetration at competitive prices, concentration through backward integration is to establish relationships with suppliers, fore the concentration through integration with how to take over the function of the overall distribution, concentration through horizontal integration with a collaborative effort with the work on the market continues to foster relationships with several similar companies that are members of the association of Mushroom's Company that exist or may hold a joint venture with the company.
\end{abstract}

Keywords: Strategy, Mushroom, Internal \& External

Abstrak. Rimba Jaya Mushroom sebagai perusahaan yang bergerak di bidang industri agribisnis dalam pengadaan sayuran dan jamur menghadapi permasalahan yakni: permintaan yang belum terpenuhi, kapasitas produk yang belum memenuhi permintaan pasar dan adanya persaingan dari perusahaan yang harus dicermati. Oleh karena itu, perusahaan memerlukan langkah yang strategis untuk mengambangkan usaha jamur dalam menghadapi masalah guna meraih peluang agar kontinuitas dan tujuan perusahaan dapat tercapai.

Penelitian ini bertujuan untuk mengidentifikasi faktor-faktor lingkungan internal (Kekuatan,Kelemahan) dan faktor-faktor lingkungan eksternal (Peluang-Ancaman) yang mempengaruhi pemasaran perusahaan, dan menganalisis strategi pemasaran Rimba Jaya Mushroom.

Berdasarkan hasil analisis matriks diagram SWOT dan diagram IE maka dapat direkomendasikan strategi pemasaran perusahaan Rimba Jaya Mushroom, antara lain dengan merebut pangsa pasar untuk penetrasi pasar dengan harga yang kompetitif, konsentrasi melalui integrasi kebelakang yaitu dengan menjalin hubungan dengan pemasok, konsentrasi melalui integrasi ke depan, yaitu dengan cara mengambil alih fungsi distribusi secara keseluruhan, konsentrasi melalui integrasi horizontal dengan upaya kerja sama menggarap pasar dengan terus membina hubungan dengan beberapa perusahaan sejenis yang tergabung dalam asosiasi perusahaan jamur yang ada atau mungkin mengadakan joint venture dengan perusahaan.

Kata kunci: Strategi, Jamur, Internal \& Eksternal

Indonesia mempunyai potensi yang sangat besar dalam pengembangan agribisnis, bahkan selalu menjadi sektor terkemuka (Leading Sector) dalam pembangunan nasional. Dalam Pembentukan Produk Domestik Bruto, sektor agribisnis merupakan penyumbang nilai tambah
(Value Added) terbesar dalam perekonomian sosial dan merupakan sektor yang menyerap tenaga kerja diperkirakan sebesar $74 \%$ total penyerapan tenaga kerja nasional. Oleh karena itu, pertanian harus diurus dan dikelola, dilindungi dan dimanfaatkan secara 
berkesinambungan bagi kesejahteraan masyarakat Indonesia, baik generasi sekarang maupun yang akan datang. Selain itu, sektor pertanian memberikan sumbangsih bagi sektor lainnya, yaitu sektor industri pangan yang sebagian besar bahan baku digunakan berasal dari produk pertanian. Selain itu sektor pertanian memberikan kontribusi yang besar terhadap penyediaan lapangan kerja di bidang tanaman bahan makanan.

Sektor agribisnis berperan dalam penyediaan pangan bagi masyarakat dalam penyediaan kebutuhan masyarakat akan sayuran dan buah-buahan. Kecenderungan masyarakat dalam mengonsumsi sayuran terus meningkat akibat dari pola hidup sehat yang telah menjadi gaya hidup masyarakat. Hal tersebut dapat berpengaruh terhadap perkembangan bisnis jamur yang merupakan salah satu jenis tanaman sayuran. Salah satu jenis komoditas sayur yang berpotensi adalah jamur. Dewasa ini jamur telah menjadi kebutuhan masyarakat, yaitu sebagai bahan pangan alternatif yang disukai oleh semua lapisan masyarakat yang berpotensi untuk dikembangkan dan mendatangkan nilai ekonomi bagi masyarakat.

Rimba Jaya Mushroom merupakan salah satu perusahaan agribisnis yang bergerak di bidang sayuran yang terletak di daerah Gadog Bogor. Berdasarkan hasil studi Pendahuluan, perusahaan ini memproduksi sayuran yang dibagi kedalam dua divisi, yakni divisi sayuran organik dan divisi jamur. Berdasarkan hasil wawancara dengan pemilik perusahaan, di antara dua divisi yang diusahakan, yaitu divisi usaha jamur yang masih memerlukan penanganan lebih lanjut, karena di samping memiliki prospek yang cerah di masa yang akan datang, yakni: harga yang relatif stabil dan teknologi yang mudah terkontrol dan bisa dipanen hingga tiga kali dalam masa panen. Masih terdapat permasalahan dalam perusahaan, yakni: permintaan yang belum terpenuhi, kapasitas produk yang belum memenuhi permintaan pasar dan adanya persaingan dari perusahaan yang harus dicermati. Oleh karena itu, perusahaan memerlukan langkah yang strategis untuk mengembangkan usaha jamur dalam menghadapi masalah guna meraih peluang agar kontinuitas dan tujuan perusahaan dapat tercapai.

Identifikasi masalah dalam penelitian ini bahwa keberhasilan kegiatan pemasaran dalam memenangkan persaingan agribisnis dan untuk mencapai tujuan perusahaan terutama pencapaian target pendapatan, sangat dipengaruhi oleh berbagai faktor, di antaranya adalah dengan pelaksanaan strategi pemasaran. Selanjutnya, dapat dibuat perumusan masalah pada penelitian ini, adalah bagaimanakah faktor-faktor lingkungan internal dan eksternal Rimba Jaya Mushroom, dan bagaimana strategi pemasaran yang harus diterapkan Rimba Jaya Mushroom.

Penelitian ini bertujuan untuk mengidentifikasi faktor-faktor lingkungan internal (Kekuatan,-Kelemahan) dan faktorfaktor lingkungan eksternal (PeluangAncaman) yang memengaruhi pemasaran perusahaan, serta menganalisis strategi pemasaran Rimba Jaya Mushroom berdasarkan Matrik SWOT dan Matrik IE.jamur

\section{LANDASAN TEORI}

Manajemen strategi dapat didefinisikan sebagai berikut:

David (2004: 5), "Seni dan pengetahuan untuk merumuskan, mengimplementasikan, dan mengevaluasi keputusan lintas fungsional yang membuat organisasi mampu mencapai objektifnya."

David (2004: 5), "Fokus manajemen strategi terletak pada memadukan manajemen, pemasaran, keuangan/akunting, produksi/operasi, penelitian dan pengembangan serta sistem informasi komputer untuk mencapai keberhasilan organisasi."

Kotler dan Amstrong (2003: 81), "Strategi pemasaran adalah pola pikir pemasaran yang akan digunakan oleh unit bisnis untuk mencapai tujuan pemasarannya."

Kotler dan Amstrong (2003:82), "Strategi pemasaran merupakan proses merangkum pola pikir pemasaran secara umum yang ingin digunakan oleh unit bisnis untuk mencapai tujuan pemasaran dan secara lebih spesifik menyatakan pasar yang akan dibidik, penetapan 


\begin{tabular}{|c|c|c|c|}
\hline \multicolumn{4}{|c|}{ Tahap Pengumpulan Data } \\
\hline Evaluasi Faktor & Evaluasi Faktor & & Matrik Profil \\
\hline Eksternal & Internal & & Kompetitif \\
\hline & 2. Tahap Analisis & & \\
\hline Matrik TOWS & $\begin{array}{l}\text { Matrik Internal } \\
\text { Eksternal }\end{array}$ & Matrik Space & $\begin{array}{c}\text { Matrik Grand } \\
\text { Strategy }\end{array}$ \\
\hline \multicolumn{4}{|c|}{ 3. Tahap Pengambilan Keputusan } \\
\hline
\end{tabular}

Gambar 1. Kerangka Formulasi Strategi

posisi dan tingkatan pengeluaran pemasarannya. Bagian ini merangkum strategistrategi secara spesifik untuk setiap elemen bauran pemasaran dan menjelaskan bagaimana masing-masing strategi itu merespons ancaman, peluang dan isu-isu penting yang dilontarkan dalam bagian rencana sebelumnya."

\section{Analisis Lingkungan Internal dan Eksternal}

Kotler dan Amstrong (2003: 101). "Lingkungan internal adalah berbagai kegiatan yang dekat dengan perusahaan yang mempengaruhi kemampuannya melayani pelanggannya, perusahaan, pemasok, perusahaan saluran pemasaran, pasar pelanggan, pesaing dan masyarakat."

Umumnya, perusahaan harus memonitor kekuatan-kekuatan lingkungan makro utama (demografi, ekonomi, teknologi, politik/hukum, sosial/budaya) yang dapat memengaruhi usaha. Dan juga terus memonitor pelaku-pelaku lingkungan mikro yang utama (pelanggan, pesaing saluran distribusi, pemasok) yang akan memengaruhi kemampuan perusahaan untuk mendapatkan keuntungan tersebut.

\section{METODE PENELITIAN}

\section{Pendekatan Penelitian}

Penelitian ini dilakukan sejak Juli 2013 sampai dengan Desember 2013, yang dilaksanakan di perusahaan Rimba Jaya Mushroom Bogor.

Pendekatan penelitian yang dilakukan adalah "Penelitian non-Eksperimen" dengan metode kualitatif dan kuantitatif. Data yang dibutuhkan dalam penelitian ini, meliputi data primer dan skunder. Sedangkan, data yang digunakan untuk menunjang hasil penelitian ini diperoleh dengan metode pengumpulan data, sebagai berikut: (1) Observasi, Studi dengan melakukan pengamatan langsung di lapangan dan melakukan pengumpulan data serta informasi berdasarkan bukti-bukti yang ada; (2) Expert Adjudement, Data diperoleh berdasarkan pendapat beberapa orang pakar dalam bidang agribisnis, yaitu pimpinan Rimba Jaya Mushroom dan beberapa tenaga ahli; (3) Studi Pustaka, Dilakukan untuk memperoleh data lain yang berhubungan dengan judul penelitian dengan menyadur teori-teori dari berbagai literatur yang mendukung.

Rangkuti (2002: 22) Tahap proses penyusunan perencanaan strategi adalah melalui tiga tahap analisis, yaitu: 1) Tahap pengumpulan data, 2) Tahap analisis, dan 3) Tahap pengambilan keputusan. Seperti terlihat pada gambar 1

Berdasarkan kerangka formulasi strategi di atas maka selanjutnya kerangka penelitian ini adalah seperti pada gambar $\mathbf{2}$ :

Pengumpulan data penelitian ini merupakan tahapan kegiatan pengklasifikasian dan pra-analisis., yaitu dengan mengidentifikasi faktor-faktor lingkungan yaitu, dengan mengidentifikasi faktor-faktor lingkungan internal dan eksternal perusahaan: (a) Data Internal. Diperoleh di dalam perusahaan itu sendiri, seperti: Laporan keuangan, Laporan kegiatan sumber daya manusia, mengkaji Laporan kegiatan operasional, Laporan kegiatan pemasaran., keuangan, produksi, akuntansi, penelitian dan pengembangan dan sistem informasi manajemen; (b) Data Eksternal. Diperoleh di luar perusahaan itu sendiri, seperti: Analisis pasar, Analisis Kompetitor, Analisis Komunitas, Analisis 


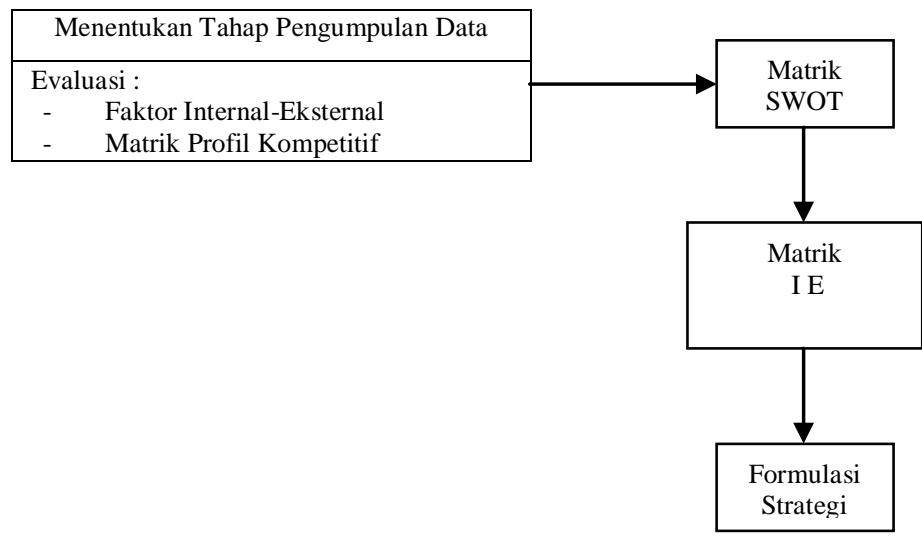

Gambar 2. Kerangka Penelitian

Pemasok, Analisis Pemerintah, Analisis kelompok kepentingan tertentu.

Untuk melakukan tahapan tersebut, maka dilakukan pengisisan kuesioner dan wawancara kepada pihak manajemen perusahaan selaku pasar.

\section{Analis Data}

Data internal dan eksternal yang telah dikumpulkan, selanjutnya sesuai peruntukkannya diadakan pengolahan dan analisis langkah-langkah sebagai berikut: (a) Analisis faktor-faktor internal: Analisis ini mencakup profil kekuatan dan kelemahan (environmental stregth \& weakness profile) yang mempengaruhi terhadap kinerja perusahaan Rimba Jaya Mushroom. Yang selanjutnya di masukkan ke dalam Matrik Evaluasi Faktor Internal (IFE) untuk dievaluasi; (b) Analisis faktor-faktor eksternal: Analisis ini mencakup profil ancaman dan peluang (environmental threat \& opportunity profile). Profile ancaman dan peluang dari lingkungan eksternal perusahaan, Yang selanjutnya di masukkan kedalam Matrik Evaluasi Faktor Eksternal (EFE) untuk dievaluasi; (c) Tahap Evaluasi Matrik: Tahap ini dilakukan dengan cara mengalikan bobot faktor dengan rating, untuk memperoleh nilai pembobotan; (d) Matrik Profil Kompetitif: Matrik profil kompetitif digunakan untuk mengetahui proses relatif perusahaan yang dianalisis dan dibandingkan dengan perusahaan pesaing. Nilai rating dimulai dari 1 , jika perusahaan tersebut kondisinya sangat lemah dibandingkan dengan pesaing. Nilai 2 diberikan pada perusahaan yang kondisinya sedikit lebih lemah dibandingkan dengan pesaing. Nilai 3 diberikan kepada perusahaan yang memiliki kondisi sedikit lebih kuat dibandingkan dengan pesaing. Sedangkan, nilali tertinggi 4 , diberikan kepada perusahaan yang memiliki kondisi paling kuat dibandingkan dengan perusahaan lainnya. Selanjutnya, untuk masing-masing perusahaan, nilai rating ini dikalikan dengan nilai bobot dari variabel yang dipergunakan.

\section{Analisis Strategi SWOT}

Penelitian ini menunjukkan bahwa kinerja perusahaan dapat ditentukan oleh kombinasi faktor internal dan eksternal. Kedua faktor tersebut harus dipertimbangkan dalam analisis SWOT. SWOT formulasi alternatif strategi dilakukan dengan menganalisis peluang (opportunities), ancaman (threats), kekuatan (strengths) dan kelemahan (weakness) yang diperoleh melalui identifikasi lingkungan eksternal dan internal. Identifikasi kekuatan dalam analisis keunggulan kompetetif ditunjukkan dengan keadaan suatu atribut yang mendukung. Sedangkan, kelemahan ditunjukkan dengan keadaan atribut yang kurang mendukung. Alat analisis yang digunakan untuk menyususun formulasi strategi tersebut adalah matriks SWOT. Matriks ini menggambarkan secara jelas bagaimana peluang dan ancaman dapat disesuaikan dengan kekuatan dan kelemahan. Matrik SWOT 
Tabel 1. Analisis Matrik SWOT

\begin{tabular}{|c|c|c|}
\hline $\begin{array}{r}\text { Faktor } \\
\text { Internal }\end{array}$ & $\begin{array}{l}\text { Kekuatan (S) } \\
\text { Daftar kekuatan }\end{array}$ & $\begin{array}{l}\text { Kelemahan (W) } \\
\text { Daftar kelemahan }\end{array}$ \\
\hline $\begin{array}{l}\text { Faktor } \\
\text { Eksternal }\end{array}$ & & \\
\hline $\begin{array}{c}\text { Peluang }(\mathbf{O}) \\
\text { Daftar peluang-peluang }\end{array}$ & $\begin{array}{c}\text { Strategi S-O } \\
\text { Membuat strategi dengan } \\
\text { menggunakan kekuatan untuk } \\
\text { memanfaatkan peluang }\end{array}$ & $\begin{array}{c}\text { Strategi W-O } \\
\text { Membuat strategi yang } \\
\text { memanfaatkan peluang untuk } \\
\text { mengatasi kelemahan }\end{array}$ \\
\hline $\begin{array}{c}\text { Ancaman (T) } \\
\text { Daftar ancaman-ancama eksternal }\end{array}$ & $\begin{array}{c}\text { Strategi S-T } \\
\text { Membuat strategi yang } \\
\text { menggunakan kekuatan untuk } \\
\text { menghindari ancaman }\end{array}$ & $\begin{array}{c}\text { Strategi W-T } \\
\text { Membuat strategi yang } \\
\text { meminimumkan kelemahan dan } \\
\text { menghindari ancaman }\end{array}$ \\
\hline
\end{tabular}

merupakan alat pencocokan yang penting yang membantu manajer mengembangkan empat tipe strategi: Strategi SO, Strategi WO, Strategi ST, Strategi WT. Mencocokkan faktor eksternal dan internal kunci merupakan bagian sulit terbesar untuk mengembangkan Matriks SWOT dan memerlukan penilaian yang baik, dan tidak ada satu pun kecocokan terbaik.

Terdapat delapan langkah dalam menyusun matriks SWOT, yaitu: (1) Menentukan faktor-faktor peluang eksternal organisasi atau perusahaan; (2) Menentukan faktor-faktor ancaman organisasi atau perusahaan; (3) Menentukan faktor-faktor kekuatan organisasi atau perusahaan: (4) Menentukan faktor-faktor kelemahan organisasi atau perusahaan; (5) Strategi S-O adalah strategi yang bersifat agresif, yaitu memaksimalkan kekuatan yang dimiliki untuk memanfaatkan peluang yang ada. Strategi ini direkomendasikan agar perusahaan dapat bersaing dalam suatu industri yang sedang tumbuh dan diharapkan terus tumbuh cukup tinggi. (6) Strategi W-O. adalah strategi yang bersifat intensif yaitu strategi yang memanfaatkan peluang yang ada dengan cara meminimalkan kelemahan yang dimiliki; (7) Strategi S-T. adalah strategi yang bersifat diverifikasi yaitu strategi yang memanfaatkan kekuatan yang dimiliki untuk menghadapi ancaman; (8) Strategi W-T. adalah strategi yang bersifat defesif, yaitu strategi yang dilakukan untuk mengatasi ancaman yang ada dan kelemahan yang dimiliki. Lihat tabel 1.

Berdasarkan analisis matrik di atas, maka perusahaan dapat memetakan situasi persaingan dan eksistensi perusahaan sekarang dan di masa akan datang. Dalam hal ini kekuatan digunakan untuk mengatasi kelemahan, dan ancaman yang ada dibuat menjadi peluang pasar.

Dengan demikian akan diperoleh tingkat daya saing, berdasarkan keunggulan kompetitif perusahaan. Posisi tersebut menggambarkan perusahaan pada kondisi internal dan eksternal yang mana?

Kuadran 1: Situasi menguntungkan Perusahaan memiliki peluang dan kekuatan. Strategi yang harus diterapkan adalah mendukung kebijakan pertumbuhan yang agresif (Growth oriented Srategy.)

Kuadran 2: Meskipun mendapat berbagai ancaman, perusahaan masih memiliki kekuatan dari segi internal. Strategy yang harus diterapkan adalah menggunakan kekuatan untuk memanfaatkan peluang jangka panjang dengan cara strategi diversifikasi (Produk/Pasar).

Kuadran 3: Perusahaan menghadapi peluang pasar yang sangat besar, tetapi dilain pihak, menghadapi beberapa kelemahan/kendala internal. Fokus strategi perusahaan adalah meminimalkan masalahmasalah internal perusahaan, sehingga dapat merebut peluang pasar yang lebih baik.

Kuadran 4: Situasi yang sangat tidak menguntungkan. Perusahaan tersebut menghadapi berbagai ancaman dan kelemahan internal.

Lihat gambar 3.

Analisis Strategi Matriks Internal Eksternal (IE) 


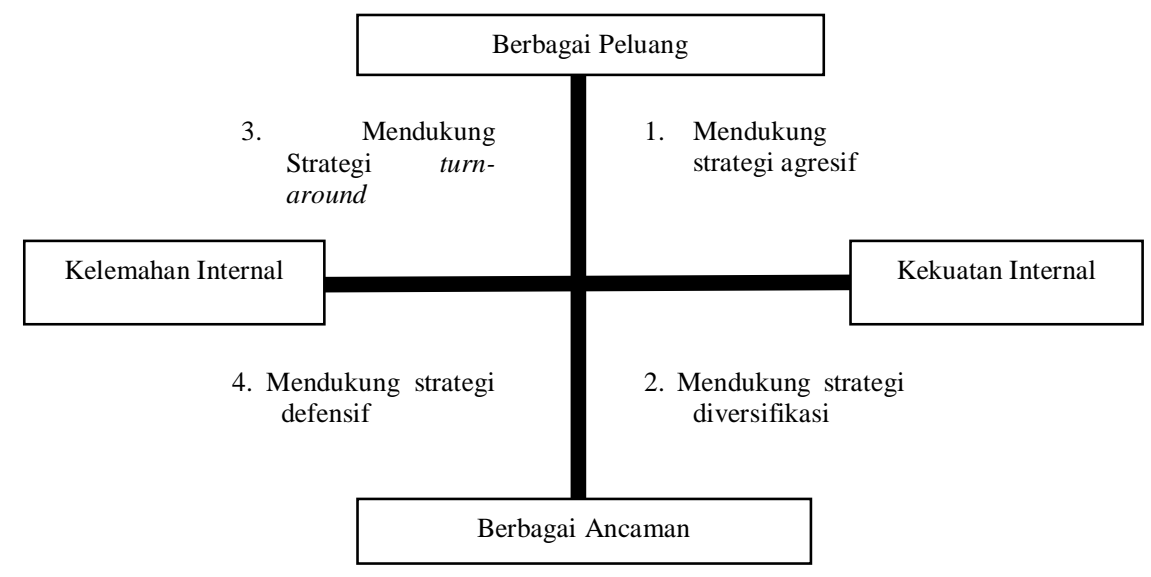

\section{Gambar 3. Analisis SWOT}

Gabungan matriks IFE dan EFE menghasilkan matriks IE yang berisi sembilan macam sel yang memperlihatkan kombinasi total nilai bobot dari matriks-matriks IFE dan EFE. Tujuan penggunaan matriks ini untuk memperoleh strategi bisnis ditingkat unit bisnis yang lebih detail. Matriks IE dapat mengidentifikasikan sembilan sel strategi, tetapi pada prinsipnya kesembilan sel ini dapat dikelompokkan menjadi tiga bagian utama yang memiliki dampak strategi yang berbeda, yaitu; (1) Divisi yang termasuk ke dalam sel I, II, IV dapat menggunakan strategi tumbuh dan bina (growth and build). Strategi yang tepat untuk keadaan ini adalah berupa strategi intensif (penetrasi pasar, pengembangan pasar, dan pengembangan produk) atau integratif (integrasi ke belakang, integrasi ke depan, dan integrasi horizontal); (2) Divisi yang masuk ke dalam sel III, V, VII, dapat menggunakan strategi pertahankan dan pelihara (hold and maintain). Strategi yang dapat dilakukan adalah dapat berupa penetrasi pasar dan pengembangan produk; (3) Divisi yang masuk ke dalam sel VI, VIII, atau IX, strategi yang dapat diterapkan adalah panen atau divestasi (harvest or divestiture).

Matriks IE didasarkan pada dua dimensi kunci, total nilai IFE yang diberi bobot pada sumbu-x dan total nilai EFE yang diberi bobot pada sumbu-y. Pada sumbu-x matriks IE, total nilai, total nilai IFE yang diberi bobot dari 1,0-
1,99 menunjukkan posisi internal yang lemah, nilai dari 2,0-2,99 dianggap sedang dan 3,0-4,0 kuat. Demikian pula pada sumbu-y, total nilai EFE yang diberi bobot 1,0-1,99 dianggap rendah, nilai 2,0-2,99 sedang dan 3,0-4,0 tinggi.

Lihat tabel 2.

\section{HASIL PENELITIAN DAN PEMBAHASAN}

\section{Faktor Lingkungan Internal Perusahaan}

Dari hasil identifikasi lingkungan internal yang mencakup analisis lingkungan analisis lingkungan industri mikro, maka dapat diketahui kekuatan, kelemahan yang dihadapi oleh perusahaan. Seperti terlihat pada tabel 3:

\section{Faktor Lingkungan Eksternal Perusahaan}

Dari hasil identifikasi lingkungan eksternal yang mencakup analisis lingkungan umum dan analisis lingkungan industri, maka dapat diketahui peluang dan ancaman yang dihadapi oleh perusahaan, seperti terlihat pada tabel 4:

\section{Matrik Profil Kompetitif}

Perusahaan Rimba Jaya Mushroom kondisinya berada di tengah-tengah dengan total skor 2,8. Meskipun dalam penguasaan pasar lebih unggul (Rating 4) dan kualitas produk (Rating 4). Skor total PT Z masih lebih 
Tabel 2. Matriks Internal-Eksternal

Total Score IFE

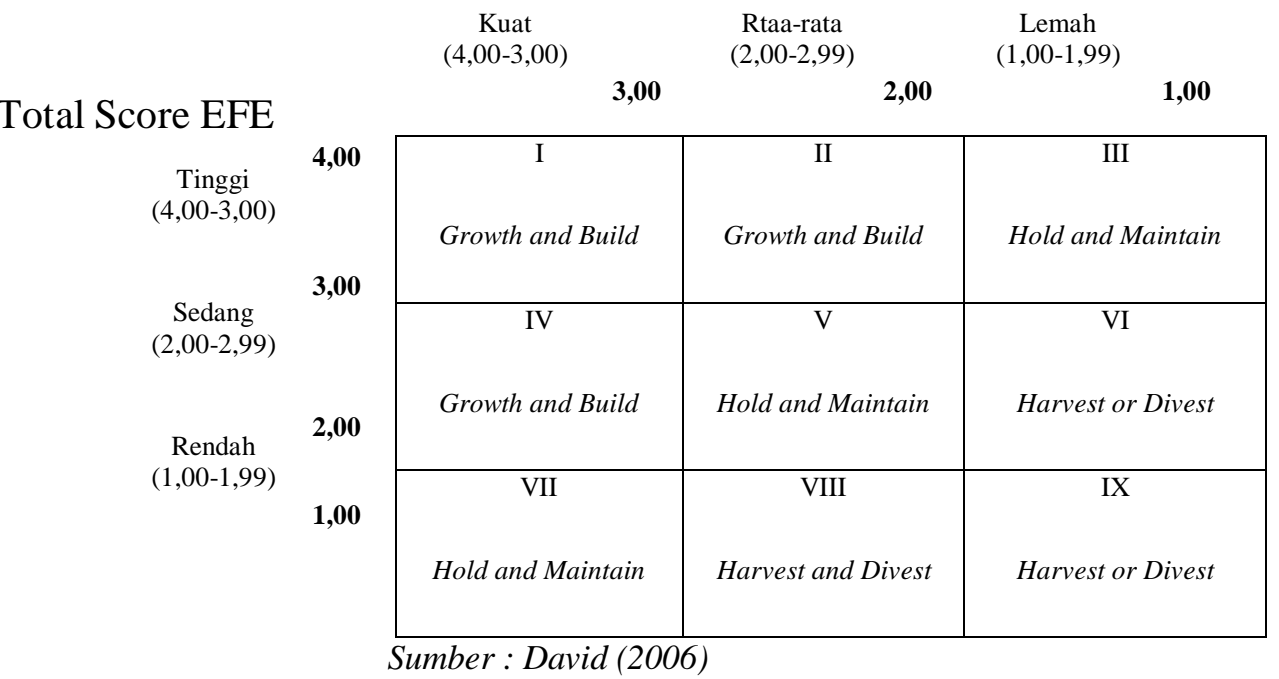

Tabel 3. Faktor-faktor Lingkungan Internal

\begin{tabular}{|c|c|c|}
\hline $\begin{array}{c}\text { Faktor } \\
\text { Internal }\end{array}$ & Kekuatan & Kelemahan \\
\hline \multirow[t]{3}{*}{$\begin{array}{l}\text { Produksi } \\
\text { dan Operasi }\end{array}$} & $\begin{array}{l}\text { - Mampu } \\
\text { memproduksi dan } \\
\text { bibit jamur sendiri }\end{array}$ & $\begin{array}{lr}\text { - Kapasitas } & \text { produksi } \\
\text { belum } & \text { mampu } \\
\text { memenuhi } & \end{array}$ \\
\hline & $\begin{array}{l}\text { - Lahan untuk } \\
\text { pengembangan } \\
\text { usaha jamur yang } \\
\text { masih luas }\end{array}$ & permintaan \\
\hline & $\begin{array}{lr}\text { - Fasilitas } & \text { produksi } \\
\text { untuk } & \text { budidaya } \\
\text { jamur baik } & \end{array}$ & \\
\hline $\begin{array}{l}\text { Manajemen } \\
\text { dan SDM }\end{array}$ & $\begin{array}{l}\text { - Tenaga kerja yang } \\
\text { kompeten dibidang } \\
\text { jamur }\end{array}$ & \\
\hline Keuangan & & $\begin{array}{l}\text { - Keterbatasan modal } \\
\text { untuk } \\
\text { mengembangkan } \\
\text { usaha } \\
\text { - Sistem administrasi } \\
\text { dan keuangan yang } \\
\text { masih sederhana }\end{array}$ \\
\hline Pemasaran & $\begin{array}{l}\text { - Kualitas produk } \\
\text { jamur baik } \\
\text { - Lokasi strategis } \\
\text { - Harga jamur mampu } \\
\text { bersaing }\end{array}$ & $\begin{array}{l}\text { - Masih kurangnya } \\
\text { promosi }\end{array}$ \\
\hline
\end{tabular}

Tabel 4. Faktor-faktor Lingkungan Eksternal

\begin{tabular}{lllr}
\hline \multicolumn{2}{c}{ Faktor Eksternal } & \multicolumn{1}{c}{ Peluang } & Ancaman \\
\hline Lingku & Politik dan & Keberadaan & \\
ngan & Kebijakan & Lembaga \\
Umum & Pemerintah & $\begin{array}{l}\text { asosiasi bagi } \\
\text { pengusaha }\end{array}$ & \\
& & jamur \\
& & & \\
& Ekonomi & - Kenaikan harga & - Peningkatan \\
& & jamur & harga BBM \\
& & - Peningkatan & - Peningkatan \\
& & permintaan & impor jamur \\
& & jamur &
\end{tabular}




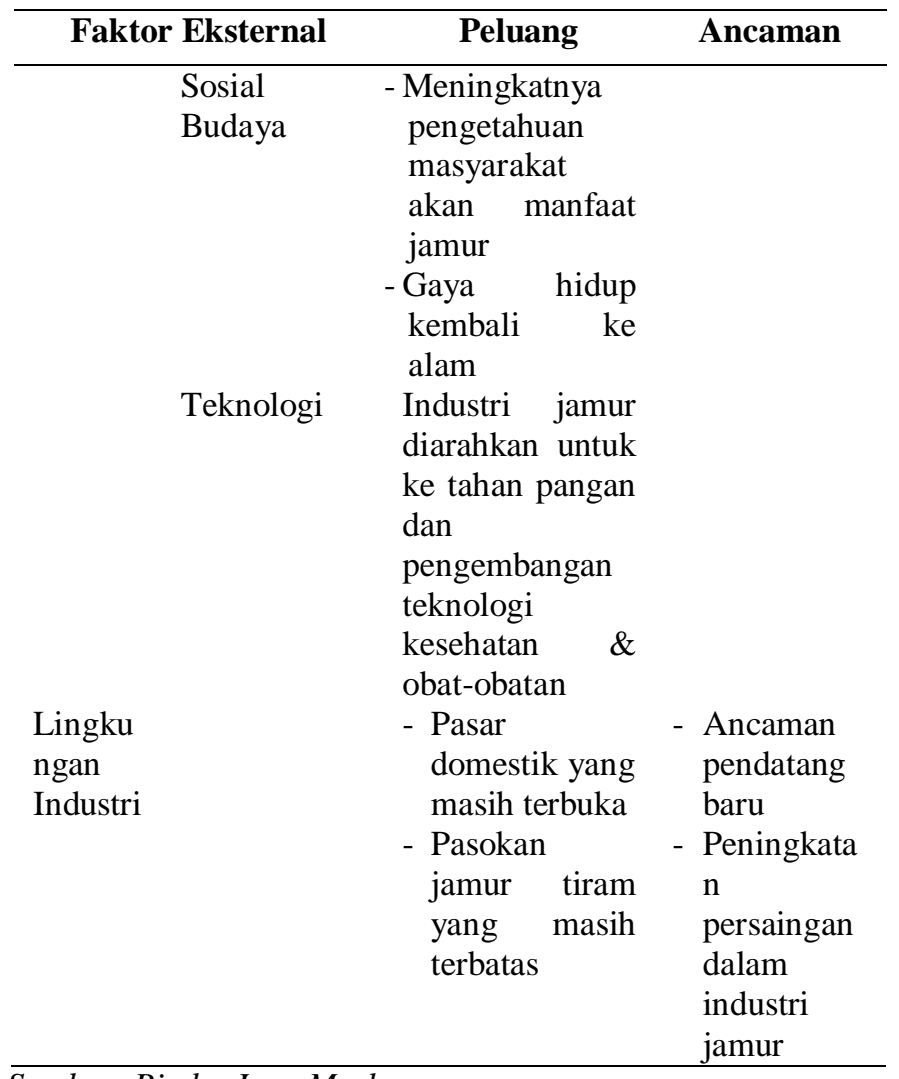

tinggi, yaitu 3,2. Ini karena yang menjadi pertimbangan penting adalah kondisi keuangan dengan bobot terbesar, yaitu 1,2. Dengan memiliki kondisi keuangan yang sangat kuat, PT Z dapat menduduki posisi tertinggi. Lihat Tabel 5.

\section{Analisis Strategi Matriks Strengths, Weakness, Opportunities, and Threats (SWOT)}

Berdasarkan hasil analisis matriks SWOT, diperoleh beberapa alternatif strategi, yaitu strategi SO, strategi WO, strategi ST, dan strategi WT.

Alternatif strategi yang diperoleh adalah: (1) Strategi S-O: (a) Menambah area produksi perusahaan melalui penambahan kumbung jamur.Perusahaan dapat membangun kumbung baru untuk meningkatkan kapasitas produksi perusahaan karena minat masyarakat yang semakin tinggi untuk mengkonsumsi makanan yang bersifat organik dan menyehatkan seperti jamur turut memperbesar peluang pasar, (b) Perusahaan membuat suplemen dengan bahan dasar jamur. Kekuatan perusahaan dengan berupa kualitas produk jamur baik dan tenaga kerja yang kompeten di bidang jamur. Peluang usaha yang ada meningkatnya pengetahuan masyarakat akan manfaat jamur dan industri jamur diarahkan untuk ketahanan pangan dan pengembangan teknologi kesehatan dan obatobatan; (2) Strategi W-O: (a) Meningkatkan promosi jamur. Kelemahan perusahaan ini adalah masih kurangnya promosi jamur. Peluang usaha yang ada berupa pengetahuan masyarakat akan manfaat jamur dan peningkatan permintaan jamur. Hal ini dapat lebih ditingkatkan dengan mengiklankan perusahaan Rimba Jaya Mushroom melalui media elektronik seperti televisi, radio, majalah, koran, (b) Mencari dana tambahan. Kelemahan perusahaan berupa kapasitas belum optimal dan keterbatasannya modal untuk mengembangkan usaha. Peluang usaha yang ada kenaikan harga jamur dan peningkatan permintaan jamur. Dengan adanya dana tambahan, perusahaan dapat meningkatkan produksi jamur dan pendapatan perusahaan; (3) Strategi S-T: (a) Peningkatan Efisiensi produksi untuk meningkatkan daya saing perusahaan. Kekuatan perusahaan berupa kualitas produksi jamur baik, dan lokasi perusahaan yang 
Tabel 5. Matrik Profil Kompetitif

\begin{tabular}{|c|c|c|c|c|c|c|c|c|c|}
\hline \multirow{2}{*}{$\begin{array}{c}\text { Faktor } \\
\text { Strategis }\end{array}$} & \multirow{2}{*}{ Bobot } & \multicolumn{2}{|c|}{$\begin{array}{l}\text { Rimba Jaya } \\
\text { Mushroom }\end{array}$} & \multicolumn{2}{|c|}{ PT X } & \multicolumn{2}{|c|}{ PT Y } & \multicolumn{2}{|c|}{ PT Z } \\
\hline & & Rating & $\begin{array}{l}\text { Bobot } \\
\text { Skor }\end{array}$ & Rating & $\begin{array}{c}\text { Bobot } \\
\text { Skor }\end{array}$ & Rating & $\begin{array}{l}\text { Bobot } \\
\text { Skor }\end{array}$ & Rating & $\begin{array}{l}\text { Bobot } \\
\text { Skor }\end{array}$ \\
\hline Pangsa pasar & 0,20 & 4 & 0,8 & 2 & 0,4 & 2 & 0,4 & 3 & 0,6 \\
\hline $\begin{array}{l}\text { Penerapan } \\
\text { harga }\end{array}$ & 0,20 & 3 & 0,6 & 2 & 0,4 & 2 & 0,4 & 3 & 0,6 \\
\hline $\begin{array}{l}\text { Posisi } \\
\text { keuangan }\end{array}$ & 0,40 & 2 & 0,8 & 1 & 0,4 & 2 & 0,8 & 3 & 1,2 \\
\hline $\begin{array}{l}\text { Kualitas } \\
\text { produk }\end{array}$ & 0,10 & 4 & 0,4 & 2 & 0,2 & 3 & 0,3 & 4 & 0,4 \\
\hline $\begin{array}{l}\text { Kesetiaan } \\
\text { konsumen }\end{array}$ & 0,10 & 2 & 0,2 & 1 & 0,1 & 3 & 0,3 & 4 & 0,4 \\
\hline Total & 1,00 & & 2,8 & & 1,5 & & 2,2 & & 3,2 \\
\hline
\end{tabular}

Sumber : Data Diolah

strategis untuk dapat menghadapi ancaman terhadap pengembangan usaha jamur berupa fluktuasi harga BBM, ancaman pendatang baru besar, dan persaingan dalam industri besar. Strategi peningkatan efisiensi produksi untuk meningkatkan daya saing perusahaan biaya produksi, (b) Kerja sama kemitraan. Dengan melakukan kerja sama kemitraan dengan perusahaan yang sejenis, yang tujuannya adalah untuk meningkatkan daya tawar perusahaan terhadap pemasok dan pembeli; (4) Strategi WT: Penghematan melalui efisiensi biaya total dalam menghadapi ancaman.

Alternatif strategi ini didapat dengan mengkombinasikan kelemahan perusahaan dengan ancaman usaha yang ada. Kelemahan perusahaan berupa kapasitas produksi belum optimal dan keterbatasannya modal untuk membangun usaha. Ancaman usaha yang dihadapi berupa fluktuasi harga BBM, peningkatan dalam industri jamur dan ancaman pendatang baru. Strategi ini dipilih jika ancaman yang dihadapi besar dan perusahaan hanya bisa bertahan saja. Dengan adanya peningkatkan kapasitas produksi jamur dalam menghadapi ancaman maka, perusahaan masih bisa bertahan.

\section{Analisis Matriks IFE}

Dalam mengidentifikasi faktor internal mencakup kekuatan (Strengths) dan kelemahan
(Weaknesses) pada perusahaan. hasil pembobotan dan pemberian rating. Berdasarkan hasil analisis diperoleh bahwa total skor IFE adalah sebesar 2,818. Berarti kondisi lingkungan internal perusahaan berada pada posisi rata-rata hasil mengidentifikasi menunjukkan bahwa perusahaan Rimba Jaya Mushroom dapat memanfaatkan kekuatan untuk mengurangi kelemahan pada perusahaan Rimba Jaya Mushroom. Lihat tabel 6:

Dapat dilihat bahwa perusahaan Rimba Jaya Mushroom kekuatan terbesar yang dimiliki melalui hasil identifikasi faktor internal yaitu kualitas jamur baik dengan skor 0.367, mampu memproduksi dan membuat bibit jamur sendiri dengan skor 0,407. Faktor lain yang juga merupakan faktor kekuatan perusahaan adalah harga jual jamur tinggi dengan skor 0,367, dan tenaga kerja yang kompeten dibidang jamur dengan skor 0,296. Identifikasi faktor kelemahan yang memiliki posisi terbesar bagi perusahaan adalah kapasitas jamur belum optimal (skor 0,133). Faktor lain juga menjadi kelemahan adalah masih kurangnya promosi jamur (skor 0,132), dan keterbatasan modal untuk membangun usaha (skor 0,149).

\section{Analisis Matriks EFE}

Dalam mengidentifikasi faktor eksternal mencakup peluang (Opportunities) dan 
Tabel 6 - Analisis Matriks IFE

\begin{tabular}{|c|c|c|c|}
\hline Faktor Kunci & Bobot & Ratting & Skor \\
\hline \multicolumn{4}{|l|}{ Kekuatan } \\
\hline $\begin{array}{l}\text { A. Mampu memproduksi } \\
\text { dan membuat bibit } \\
\text { jamur sendiri }\end{array}$ & 0,111 & 3,67 & $\begin{array}{l}0,40 \\
7\end{array}$ \\
\hline $\begin{array}{l}\text { B. Lahan untuk } \\
\text { pengembangan usaha } \\
\text { jamur yang masih luas }\end{array}$ & 0,089 & 3,33 & $\begin{array}{l}0,29 \\
6\end{array}$ \\
\hline $\begin{array}{l}\text { C. Fasilitas produksi } \\
\text { untuk budidaya jamur } \\
\text { baik }\end{array}$ & 0,105 & 3,00 & $\begin{array}{l}0,31 \\
5\end{array}$ \\
\hline $\begin{array}{l}\text { D. Tenaga kerja yang } \\
\text { kompeten dibidang } \\
\text { jamur }\end{array}$ & 0,089 & 3,33 & $\begin{array}{l}0,29 \\
6\end{array}$ \\
\hline $\begin{array}{l}\text { E. Kualitas produk jamur } \\
\text { baik }\end{array}$ & 0,100 & 3,67 & $\begin{array}{l}0,36 \\
7\end{array}$ \\
\hline F. $\begin{array}{c}\text { Harga jual jamur } \\
\text { tinggi }\end{array}$ & 0,100 & 3,67 & $\begin{array}{l}0,36 \\
7\end{array}$ \\
\hline $\begin{array}{l}\text { G. Lokasi perusahaan } \\
\text { yang strategis }\end{array}$ & 0,074 & 3,00 & $\begin{array}{l}0,22 \\
2\end{array}$ \\
\hline Kelemahan & & & \\
\hline $\begin{array}{l}\text { H. Kapasitas produksi } \\
\text { jamur belum optimal }\end{array}$ & 0,100 & 1,33 & $\begin{array}{l}0,13 \\
3\end{array}$ \\
\hline $\begin{array}{l}\text { I. Keterbatasan modal } \\
\text { untuk membangun } \\
\text { usaha }\end{array}$ & 0,089 & 1,67 & $\begin{array}{l}0,14 \\
9\end{array}$ \\
\hline $\begin{array}{l}\text { J. Sistem administrasi } \\
\text { dan keuangan yang } \\
\text { masih sederhana }\end{array}$ & 0,063 & 2,00 & $\begin{array}{l}0,12 \\
6\end{array}$ \\
\hline $\begin{array}{l}\text { K. Masih kurangnya } \\
\text { promosi jamur }\end{array}$ & 0,079 & 1,67 & $\begin{array}{l}0,13 \\
2\end{array}$ \\
\hline Total & 1,000 & & 2,81 \\
\hline
\end{tabular}

ancaman (Threats) pada perusahaan. Berdasarkan hasil analisis diperoleh bahwa total skor EFE adalah sebesar 3,095. Berarti kondisi lingkungan eksternal perusahaan berada pada posisi kuat, dan dapat merespon dengan baik terhadap peluang dan ancaman. Seperti pada tabel 7:

Peluang terbesar yang dimiliki melalui hasil identifikasi faktor eksternal perusahaan dalam pengembangan usaha pada divisi jamur adalah peningkatan harga komoditas jamur (Skor 0,480), industri jamur diarahkan untuk ketahanan pangan dan teknologi kesehatan dan obat-obatan (Skor 0,386), meningkatnya pengetahuan masyarakat akan manfaat jamur (Skor 0,363), dan kenaikan harga komoditas jamur (Skor 0,338). Dari hasil identifikasi dan analisis juga diperoleh kelemahan yang dimiliki oleh perusahaan pada divisi jamur pada perusahaan yaitu peningkatan persaingan dalam industri jamur besar (Skor 0,184), produk subtitusi yang tinggi (Skor 0,170), peningkatan impor jamur $(0,150)$ dan ancaman pendatang baru besar (skor 0,140).
Berdasarkan tabel 8 analisis IFE dan EFE selanjutnya dilakukan perhitungan selisih dalam matriks diagram SWOT.

Faktor internal yang terdiri dari kekuatan dengan skor 2,27 dan kelemahan dengan skor 0,54, maka selisih faktor internal adalah sebesar 1,73 yang didiminasi oleh kekuatan. Sedangkan faktor eksternal yang terdiri dari peluang dengan skor 2,361 dan kelemahan dengan skor 0,733, maka selisih faktor eksternal adalah sebesar 1,628 yang didominasi oleh peluang. Nilai skor pada kekuatan dan peluang menjadi koordinat posisi strategi perusahaan yang tepat yaitu pada koordinat $\mathrm{X}=1,73$ dan $\mathrm{Y}=1,628$, yang selanjutnya dimasukkan ke dalam diagram SWOT. Lihat gambar 4 berikut:

Pada gambar 4 menunjukkan titik koordinat X dan Y berada pada kuadran I yaitu ekspansi strategi ofensif hal ini menujukkan bahwa strategi yang tepat dijalankan adalah strategi SO (Strength-Opportunities): yaitu menggunakan kekuatan-kekuatan yang dimiliki perusahaan untuk mendapatkan peluangpeluang dengan: (1) Menambah area produksi perusahaan melalui penambahan kumbung 
Tabel 7. Analisis Matriks EFE

\begin{tabular}{|c|c|c|c|}
\hline Faktor Kunci & Bobot & Ratting & Skor \\
\hline \multicolumn{4}{|l|}{ Peluang } \\
\hline $\begin{array}{l}\text { A. Kenaikan harga } \\
\text { komoditas jamur }\end{array}$ & 0,093 & 3,67 & 0,338 \\
\hline $\begin{array}{l}\text { B. Keberadaan } \\
\text { Lembaga asosiasi } \\
\text { bagi pengusaha } \\
\text { jamur }\end{array}$ & 0,096 & 3,00 & 0,249 \\
\hline $\begin{array}{l}\text { C. Peningkatan } \\
\text { permintaan } \\
\text { komoditas jamur }\end{array}$ & 0,108 & 4,00 & 0,480 \\
\hline $\begin{array}{l}\text { D. Meningkatnya } \\
\text { pengetahuan } \\
\text { masyarakat akan } \\
\text { manfaat jamur }\end{array}$ & 0,096 & 3,33 & 0,363 \\
\hline $\begin{array}{l}\text { E. Industri jamur } \\
\text { diarahkan untuk } \\
\text { ketahanan pangan } \\
\text { dan teknologi } \\
\text { kesehatan dan obat- } \\
\text { obatan }\end{array}$ & 0,104 & 3,33 & 0,386 \\
\hline $\begin{array}{l}\text { F. Gaya hidup } \\
\text { kembali ke alam } \\
\text { (back to nature) }\end{array}$ & 0,058 & 3,67 & 0,257 \\
\hline $\begin{array}{l}\text { G. Pasokan jamur } \\
\text { tiram masih rendah }\end{array}$ & 0,069 & 4,00 & 0,288 \\
\hline \multicolumn{4}{|l|}{ Ancaman } \\
\hline $\begin{array}{l}\text { H. Fluktuasi harga } \\
\text { BBM }\end{array}$ & 0,058 & 1,33 & 0,089 \\
\hline $\begin{array}{l}\text { I. Peningkatan impor } \\
\text { jamur }\end{array}$ & 0,070 & 2,33 & 0,150 \\
\hline $\begin{array}{l}\text { J. Ancaman } \\
\text { pendatang baru } \\
\text { besar }\end{array}$ & 0,077 & 1,67 & 0,140 \\
\hline $\begin{array}{l}\text { K. Peningkatan } \\
\text { persaingan dalam } \\
\text { industri jamur } \\
\text { besar }\end{array}$ & 0,089 & 2,00 & 0,184 \\
\hline $\begin{array}{l}\text { L. Produk substitusi } \\
\text { yang tinggi }\end{array}$ & 0,081 & 1,67 & 0,170 \\
\hline Total & 1,000 & & 3,095 \\
\hline
\end{tabular}

Tabel 8. Analisis Matriks Diagram Matriks SWOT

\begin{tabular}{llclc}
\hline Faktor & Internal & Skor & Eksternal & Skor \\
\hline 1 & Kekuatan & 2,27 & Peluang & 2,361 \\
2 & Kelemahan & 0,54 & Ancaman & 0,733 \\
& Selisih & 1,73 & & 1,628 \\
\hline
\end{tabular}

jamur; (2) Peningkatan pangsa pasar; (3) Perusahaan membuat makanan suplemen dengan bahan dasar jamur.

\section{Analisis Diagram Matriks IE}

Pemetaan posisi perusahaan sangat penting bagi pemilihan alternatif strategi dalam menghadapi persaingan dan perubahan yang terjadi dalam pengembangan usaha. Dari hasil analisis EFE diperoleh total skor 3,096 dan analisis IFE diperoleh total skor 2,818. Total skor dari masing-masing matriks IFE dan EFE yang dimiliki oleh perusahaan Rimba Jaya Mushroom yang dipetakan dalam matriks IE dan diperoleh posisi perusahaan pada usaha jamur tiram saat ini berada di kuadran II yang 


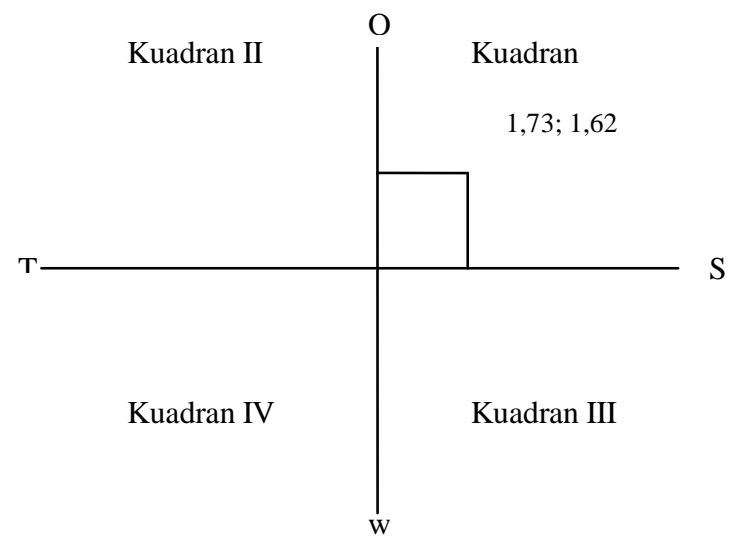

\section{Gambar 4 : Diagram SWOT}

\section{SKOR TOTAL IFE}

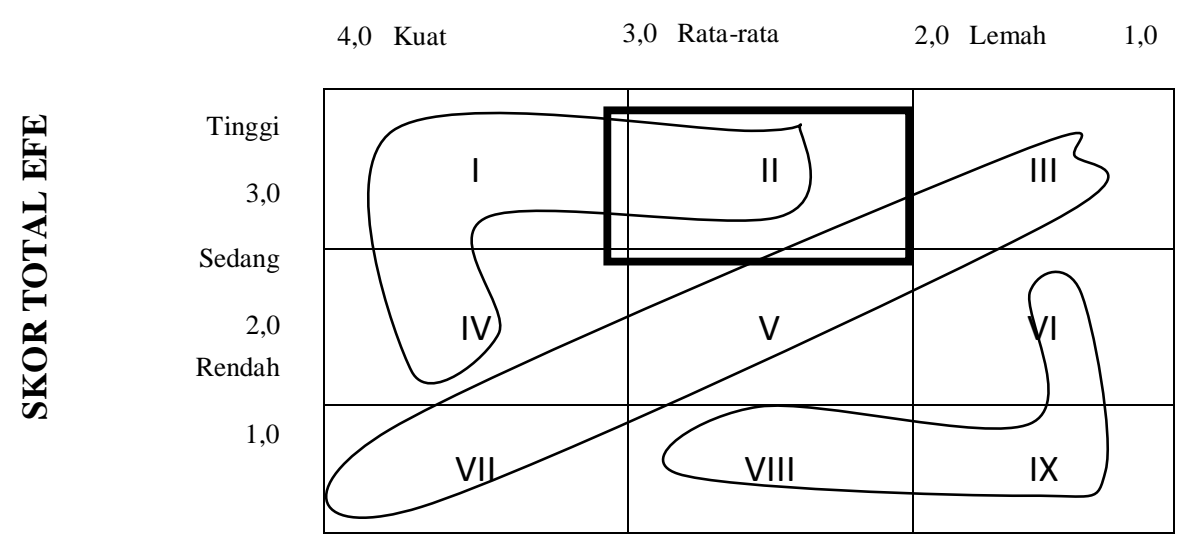

Gambar 6. Matriks Internal-Eksternal (IE Matriks) Rimba Jaya Mushroom

merupakan posisi "tumbuh dan kembangkan" (grow and build). Pada kondisi tersebut strategi yang tepat digunakan adalah strategi intensif dan strategi integratif.

Strategi intensif yang diterapkan perusahaan, yaitu starategi penetrasi pasar yang merupakan strategi untuk barang dan jasa yang ada saat ini melalui peningkatan usaha pemasaran. Strategi integrasi mencakup integrasi ke belakang, integrasi ke depan dan integrasi horizontal. Strategi pengembangan pasar merupakan strategi untuk memperkenalkan produk-produk yang sudah ada ke daerah pemasaran yang baru.

Strategi lain yang dapat diterapkan oleh perusahaan adalah pengembangan produk. Perusahaan sampai saat sekarang belum dapat memenuhi permintaan pelanggan secara kontinu. Sehingga pengembangan usaha merupakan suatu strategi yang tepat untuk perusahaan. Pengembangan usaha tersebut yang dapat dilakukan, yaitu peningkatan produksi. Sedangkan Strategi integrasi yang mencakup strategi ke belakang yang dilakukan oleh perusahaan adalah dengan menjalin hubungan dengan pemasok. Dari hasil analisis terlihat kondisi perusahaan berada pada posisi tumbuh dan bina, manajemen yang paling sesuai adalah pada posisi tersebut adalah tumbuh dan bina. Sedangkan strateginya adalah strategi intensif, yaitu penetrasi pasar, konsentrasi melalui integrasi ke belakang, konsentrasi melalui integrasi ke depan, dan konsentrasi melalui integrasi horizontal.

Berdasarkan analisis matrik IE, menunjukkan perusahaan Rimba Jaya Mushroom berada pada posisi yang cukup kuat. Adanya kenyataan tersebut untuk dapat mempertahankan laju pertumbuhan perusahaan agar tetap baik, maka strategi yang diterapkan adalah strategi intensif dan integrasi. Lihat gambar 6: 


\section{Rekomendasi Strategi Pemasaran untuk Rimba Jaya Mushroom}

Dari hasil analisis matrik pada diagram SWOT dan IE maka dapat direkomen strategi pemasaran Rimba Jaya Mushroom, antara lain: (1) Merebut pangsa pasar untuk penetrasi pasar dengan harga yang kompetitif, dapat dilakukan dengan: (a) Menata kembali harga pokok penjualan dengan menerapkan harga penawaran yang rendah dan layak dengan kualitas yang sama, (b) Meningkatkan/ menambah akses pasar yang lebih luas, (c) Menambah area produksi perusahaan, melalui penambahan kumbung, (d) Peningkatan efisiensi produksi guna meningkatkan daya saing perusahaan, (e) Mempertahankan dan meningkatkan kualitas produk, dengan terlebih dahulu meningkatkan sumberdaya internal dan eksternal di lapangan; (2) Konsentrasi melalui integrasi kebelakang yaitu menjalin hubungan dengan pemasok; (3) Konsentrasi melalui integrasi kedepan, mengambil alih fungsi distribusi secara keseluruhan, meningkatkan kinerja dilapangan, meminimalkan biaya dan operasi dalam rangka mengontrol kualitas pekerjaan agar memperoleh hasil maksimal; (4) Konsentrasi melalui integrasi horisontal, kerjasama menggarap pasar, membina hubungan dengan beberapa perusahaan sejenis dalam asosiasi perusahaan jamur yang ada, mengadakan joint venture.

\section{Simpulan}

Berdasarkan hasil dan pembahasan mengenai strategi pemasaran Rimba Jaya Mushroom dapat ditarik simpulan: (1) Hasil identifikasi faktor lingkungan Internal perusahaan, yaitu mampu memproduksi dan bibit jamur, lahan masih luas, fasilitas produksi baik, tenaga kerja kompeten, kualitas produk baik, lokasi strategis dan harga jamur mampu bersaing. kapasitas produksi belum mampu memenuhi permintaan, keterbatasan modal, sistem administrasi keuangan masih sederhana, kurangnya promosi. Hasil faktor lingkungan Eksternal yaitu keberadaan lembaga asosiasi, kenaikan harga, peningkatan permintaan jamur, meningkatnya pengetahuan masyarahat, industri jamur diarahkan untuk ke tahanan pangan \& pengembangan teknologi kesehatan dan obat-obatan, pasar domestik masih terbuka, pasokan jamur tiram yang masih terbatas dan peningkatan harga BBM dan impor jamur, ancaman pendatang baru, serta peningkatan persaingan; (2) Berdasarkan hasil analisis matriks diagram SWOT dan diagram IE maka dapat rekomendasikan strategi pemasaran perusahaan Rimba Jaya Mushroom antara lain dengan merebut pangsa pasar untuk penetrasi pasar dengan harga yang kompetitif, konsentrasi melalui integrasi ke belakang dengan menjalin hubungan dengan pemasok, konsentrasi melalui integrasi ke depan dengan cara mengambil alih fungsi distribusi secara keseluruhan, konsentrasi melalui integrasi horizontal dengan upaya kerja sama menggarap pasar terus membina hubungan dengan beberapa perusahaan sejenis atau mungkin mengadakan joint venture.

\section{DAFTAR PUSTAKA}

David, Freud. R. 2006. Manajemen Strategis. Konsep. Edisi 10. Jakarta: Salemba Empat.

Rimba Jaya Mushroom. 2010. Katalog Rimba Jaya Mushroom. Edisi Januari-Desember. Bogor: Rimba Jaya Mushroom.

Kotler, Philip. 2007. Manajemen Pemasaran. Edisi 12 Jilid 1. Edisi Bahasa Indonesia. Jakarta: PT Indeks.

Kotler, Philip. 1986. Manajemen Pemasaran. Jakarta: PT. Prenhallindo.

Kotler, Philip. 2000. Marketing Management: Prinsiples Of Marketing. Jakarta: Fakultas Ekonomi Universitas Indonesia.

Rangkuti, Freddy. 2006. Analisis SWOT Teknik Membedah Kasus Bisnis. Jakarta: Gramedia.

www.bps.go.id Biro Pusat Statistik. Data Konsumsi Per Kapita Jamur di Indonesia Periode 2004-2007. 